\title{
A Response to: Letter to the Editor Regarding Radiofrequency Treatment-Newer Modes and Long- Term Effects
}

\author{
Alaa Abd-Elsayed · Jay Karri
}

Received: June 7, 2021 / Accepted: June 17, 2021 / Published online: July 3, 2021

(C) The Author(s) 2021

Keyword: Radiofrequency; Chronic pain; Long-term effects

To the Editor,

We appreciate the comments by Dr. Raghuraman about our article on radiofrequency ablation for the sympathetic nervous system.

We fully recognize the utility of newer radiofrequency ablation modalities, i.e., cooled radiofrequency ablation and bipolar radiofrequency ablation. However, given that we identified almost no articles discussing these therapies in treating sympathetic nervous system painful conditions, we made the intentional choice to exclude these ablative therapies from our review.

As for the analysis and conclusions, we performed a narrative review article and not a meta-analysis. In our article we characterized and summarized the findings of other articles as reported by the original authors. The request Dr. Raghuraman is asking for requires a metaanalysis that will test all articles, their strengths

\footnotetext{
A. Abd-Elsayed ( $\square)$

Anesthesiology, University of Wisconsin School of Medicine and Public Health, Madison, WI, USA e-mail: alaaawny@hotmail.com

J. Karri

Department of Physical Medicine and Rehabilitation, Baylor College of Medicine, Houston, TX, USA
}

and confounders. The articles published were too heterogenous in type, intervention, cohort, and pain syndromes and thus were not sufficient to perform a meta-analysis.

Again, we thank Dr. Raghuraman for his comments. We fully agree with the need for more research in this area-notably research exploring various ablative modalities, with longitudinal follow-up and functional parameters.

Sincerely,

Alaa Abd-Elsayed, MD, MPH and Jay Karri, $\mathrm{MD}, \mathrm{MPH}$

\section{ACKNOWLEDGEMENTS}

Funding. No funding or sponsorship was received for this study or publication of this article.

Authorship. All named authors meet the International Committee of Medical Journal Editors (ICMJE) criteria for authorship for this article, take responsibility for the integrity of the work as a whole, and have given their approval for this version to be published.

Author's Contributions. Both authors contributed equally to the writing of this letter. 
Disclosures. Jay Karri and Alaa Abd-Elsayed have nothing to disclose. Dr. Abd-Elsayed is a consultant of Medtronic and Avanos.

Compliance with Ethics Guidelines. This article is based on previously conducted studies and does not contain any new studies with human participants or animals performed by any of the authors.

Open Access. This article is licensed under a Creative Commons Attribution-NonCommercial 4.0 International License, which permits any non-commercial use, sharing, adaptation, distribution and reproduction in any medium or format, as long as you give appropriate credit to the original author(s) and the source, provide a link to the Creative Commons licence, and indicate if changes were made. The images or other third party material in this article are included in the article's Creative Commons licence, unless indicated otherwise in a credit line to the material. If material is not included in the article's Creative Commons licence and your intended use is not permitted by statutory regulation or exceeds the permitted use, you will need to obtain permission directly from the copyright holder. To view a copy of this licence, visit http://creativecommons.org/licenses/by$\mathrm{nc} / 4.0 /$. 